M. KESMATI ${ }^{1}$, M. REZAI ${ }^{1}$, and M. TORABI ${ }^{1}$

\title{
MODULATORY EFFECTS OF THE GLUCOCORTICOID AND OPIOID SYSTEMS ON ANXIETY-RELATED BEHAVIOR IN YOUNG AND MATURE RATS
}

\author{
Received August 29, 2014
}

Considering that there is limited information on interaction between age and effects of the opioid system and glucocorticoids in determination of the level of anxiety, we examined the influences of $1 \mathrm{mg} / \mathrm{kg}$ dexamethasone and $20 \mathrm{mg} / \mathrm{kg}$ RU486 (as an agonist and an antagonist of glucocorticoid receptors), and also of $5 \mathrm{mg} / \mathrm{kg}$ morphine and $20 \mathrm{mg} / \mathrm{kg}$ naloxone (as an agonist and an antagonist of the opioid system) on the anxiety level in young and mature male Wistar rats. The percentage of time in the open arms in the plus-maze test was evaluated as an index of anxiety behavior, and the percentage of number of entries in the closed arms was measured as an index of locomotor activity. The results showed that morphine $(5 \mathrm{mg} / \mathrm{kg})$ and dexamethasone $(1 \mathrm{mg} / \mathrm{kg})$ exerted anxiolytic effects in both young and mature rats, while only in young rats these agents reduced locomotor activity. RU486 could prevent the anxiolytic effect of morphine, and the anxiolytic effect of dexamethasone was inhibited by naloxone in young animals but this was not observed in mature rats. These results showed that there is an interactive effect between glucocorticoids and the opioid system in mediation of anxiety, and the respective events are age-dependent.

Keywords: anxiety, opioids, glucocorticoids, RU486, naloxone, plus-maze, age dependence.

\section{INTRODUCTION}

The stress system coordinates adaptive responses of the organism to a great variety of stressors [13]. One of the main components of the stress system is the hypothalamo-pituitary-adrenal (HPA) axis; corticotrophin-releasing hormone $(\mathrm{CRH})$ and locus ceruleus-produced norepinephrine (NE) play important roles in realization of the stress responses $[1,2]$. Activation of the stress system leads to behavioral and peripheral autonomic changes improving the ability of the organism to adjust homeostasis and increasing its chances for survival [2, 3]. End hormones of the HPA axis, glucocorticoids, perform a number of roles in the organism [3]. There is evidence that disregulation of the HPA axis is significantly implicated in various pathophysiological disorders, like anxiety [4, 5]. Some studies have shown that acute injections of low doses of glucocorticoids, dexamethasone (DEX) in

\footnotetext{
${ }^{1}$ Department of Biology, Faculty of Sciences, Shahid Chamran University, Ahvaz, Iran.

Correspondence should be addressed to M. Kesmati

(e-mail: m.kesmati@ scu.ac.ir.).
}

particular, reduce the anxiety level, while in higher doses this intensifies this phenomenon in animals [6].

It has been demonstrated that opioid receptor agonists and antagonists, such as morphine and naloxone, considerably influence anxiety in animals [7-9].On the other hand, some studies showed that the opioid system can intensely affect the HPA axis activity $[6,10]$.

It has been shown that dexamethasone is able to modify the effects of opioids in the analgesia and anxiety studies, in such a way indicating for important interaction between glucocorticoids and activity of the opioid system $[7,11,12]$.

Acute activation of opioid receptors increases the activity of the HPA axis, leading to intensification of the release of $\mathrm{ACTH}$ and corticosterone in rats $[11,13]$. The pituitary-adrenocortical response to mild stress was markedly stronger in juveniles exposed to morphine than in adult individuals [14]. Morphine may either increase the perceived severity of the action of stressors or decrease the sensitivity to negative feedback effects of stress on the levels of corticosterone in juvenile males [14]. There is a striking shift in the morphine effects on the HPA 
axis across development [14]. An opioid receptor antagonist, naloxone, can inhibit the anxiolytic effect of glucocorticoids, like dexamethasone (DEX) [7].

Several variables (including age) are known to influence the anxiety levels $[15,16,17]$. It has been shown that anxiety in adolescents is less intense than that in adults [18]. There are some evidences that glucocorticoids can change various types of behavior depending on the age $[19,20]$, but there were no evidence about interrelations between age and anxiolytic effects of opiates or glucocorticoids.

In this study, we investigated the interaction between activities of the opioidergic and glucocorticoid systems whith respect to in anxiety-related behaviors in young and mature male rats.

\section{METHODS}

Animals and Treatments. The experiments were carried out on 98 male Wistar rats. 49 young (1-monthold individuals weighing 40-45 g) and 49 mature (3-month-old ones weighing 170-180 g). Animals were kept at a constant temperature $\left(22 \pm 2{ }^{\circ} \mathrm{C}\right)$ and a 12-h light/dark cycle with free access to food and water. The rats were handled 4-5 days before the tests. All experiments were done within the light phase (9 to 11 a.m.).

Animals were divided into 14 groups. Young and mature rats received (i) saline, (ii) $5 \mathrm{mg} / \mathrm{kg}$ morphine [1], (iii) $1 \mathrm{mg} / \mathrm{kg}$ DEX [21], (iv) $2.5 \mathrm{mg} / \mathrm{kg}$ morphine + $+1 \mathrm{mg} / \mathrm{kg}$ DEX, (v) $5 \mathrm{mg} / \mathrm{kg}$ morphine $+1 \mathrm{mg} / \mathrm{kg}$ DEX, (vi) $20 \mathrm{mg} / \mathrm{kg}$ RU486 (mifepristone a glucocorticoid antagonist) [22] $+5 \mathrm{mg} / \mathrm{kg}$ morphine, and (vii) $2 \mathrm{mg} / \mathrm{kg}$ naloxone $+1 \mathrm{mg} / \mathrm{kg}$ DEX. The use of effective doses of medication in this our study was based on the results of previous studies.

Drugs. Morphine (Temad Co., Iran), DEX (Iran Hormone Co., Iran), naloxone (Tolidaru Co., Iran), and RU486 (Sigma, USA) were dissolved in saline. All drugs were injected i.p. in a volume of $5 \mathrm{~cm}^{3}$ saline $/ \mathrm{kg}$.

Elevated Plus-Maze Test. The elevated plus maze set was made of wood with two open arms $(50 \times 5 \mathrm{~cm})$ and opposite closed arms of the same size, but with 40-cm-high walls. The arms were connected by a central square $(10 \times 10 \mathrm{~cm})$ and, thus, formed a plus sign. The apparatus was elevated $50 \mathrm{~cm}$ above the floor. Each rat was placed in the central square of the plus-maze set facing an enclosed arm. The time spent in the enclosed and open arms was scored for $5 \mathrm{~min}$. An arm entry was defined as an animal entered the arm with all four feet, and the number of entries into the open and enclosed arms was scored [23]. The value of total time spent in the open arm/total value) $100 \%$ was, with obvious natural reservations, considered an anxiety index, and (number of closed arm entries/total value) $100 \%$ was measured as an index of locomotor activity.

Statistical Analysis. All results are presented below as means \pm s.e.m. for seven animals per group. A twotailed Student's $t$-test was used to compare the mean frequencies of the behaviors between groups. Some data were assessed by analysis of variance (ANOVA). The subsegment post-hoc analyses (the LSD test) were performed for assessing specific group comparisons and differences, where $P<0.05$ was considered an index of statistical significance. Calculations were performed using the SPSS (version 19) statistical package.

\section{RESULTS}

Treatment of Young and Mature Rats with Morphine and/or DEX. As is shown in Fig. 1 A, the percentage of time in the open arms was dramatically greater $(P<0.001)$ after morphine $(5 \mathrm{mg} / \mathrm{kg})$ injections and also after dexamethasone (DEX) $(1 \mathrm{mg} / \mathrm{kg})(P<0.001)$ in the young group. In the adult group, this index was also increased $(P<0.05)$ by morphine (lesser than in young animals) and dexamethasone $(P<0.001)$, which showed anxiolytic effects of these agents. Also there was a significant difference between time in open arms between the control groups $(P<0.05)$ and between the morphine-receiving groups of young and adult rats $(P<0.05)$. This means that the anxiety level in adult rats is greater, and that morphine is noticeably more effective in young rats.

Closed arm entries as the index of locomotor activity decreased in young rats that received morphine $(5 \mathrm{mg} / \mathrm{kg})$ or DEX $(1 \mathrm{mg} / \mathrm{kg})$ in comparison with the control group $(\mathrm{P}<0.05)$, (Fig. 1B).

Injections of both $5 \mathrm{mg} / \mathrm{kg}$ morphine and $1 \mathrm{mg} / \mathrm{kg}$ dexamethasone dramatically (more than two times) increased the percentage of time spent by young rats in the open arms of the testing set $(P<0.001$ in both cases). Introductions of these agents exerted similar affects also on mature animals, but it should be mentioned that the intensity of such influence on these rats was much stronger than that on young individuals ( $P<0.001$ and $P<0.05$, respectively). It should also be emphasized that the normalized mean time spent by 


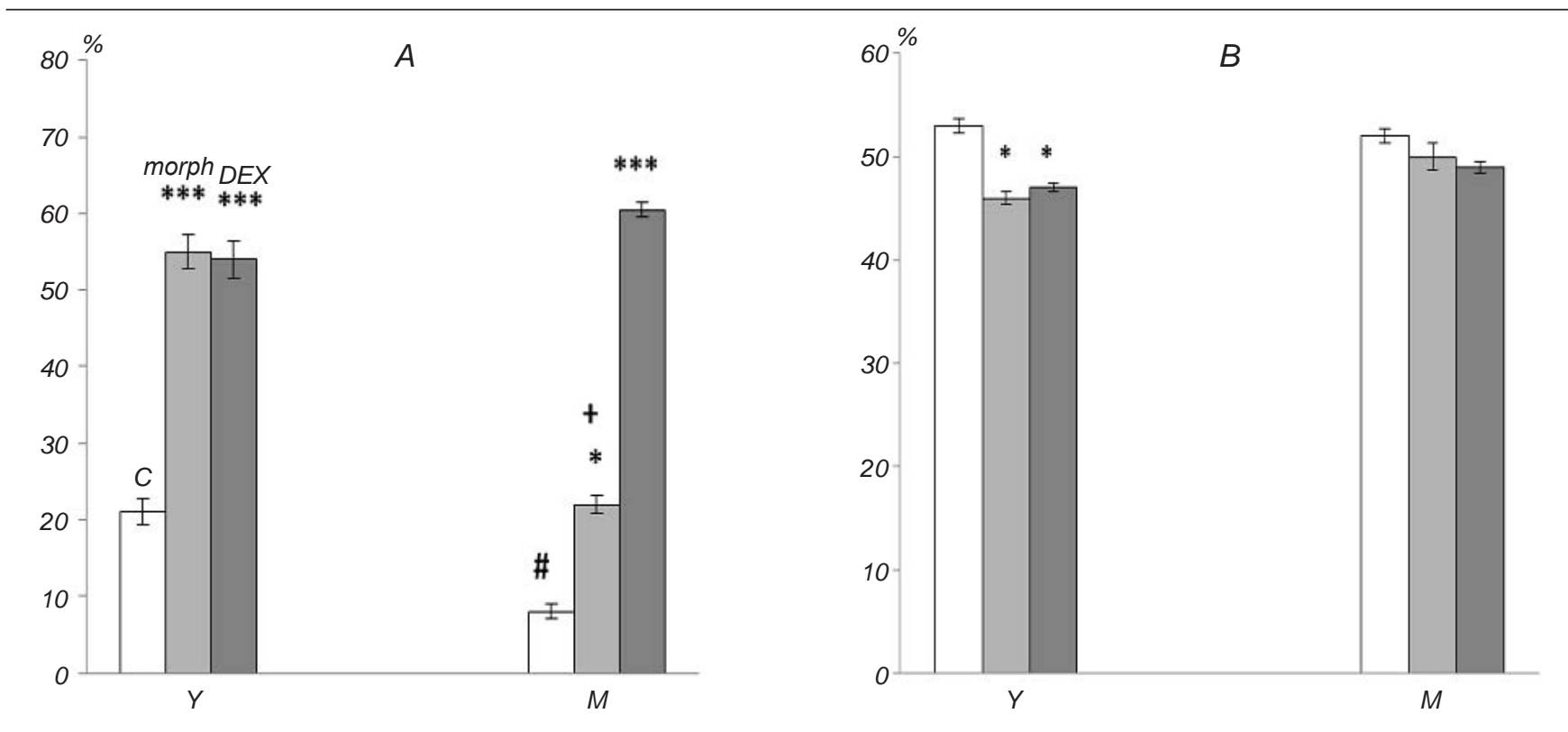

F i g. 1. Effects of morphine (morph, $5 \mathrm{mg} / \mathrm{kg}$ ) and dexamethasone (DEX, $1 \mathrm{mg} / \mathrm{kg}$ ) on anxiety (A) and locomotor activity indices (B) in rats of different age. Diagrams of normalized values, $\%$, of time spent by the animals in open arms of the testing set (A) and number of entries in closed arms (B) in young (1-month-old, Y) and mature (3-month-old, $\mathrm{M})$ rats. $* P<0.05, * * * P<0.001$ compared to the rats receiving saline (control, $\mathrm{C}$ ); ${ }^{\#} P<0.05$ in comparisons between young and mature rats; $+P<0.05$ in comparisons between young and mature rats receiving morphine, $n=7$ in all cases.

Р и с. 1. Впливи морфіну (\% мг/кг) та дексаметазону (1 мг/кг) на індекси тривожності $(A)$ та локомоторної активності $(B)$ у щурів різного віку.

A

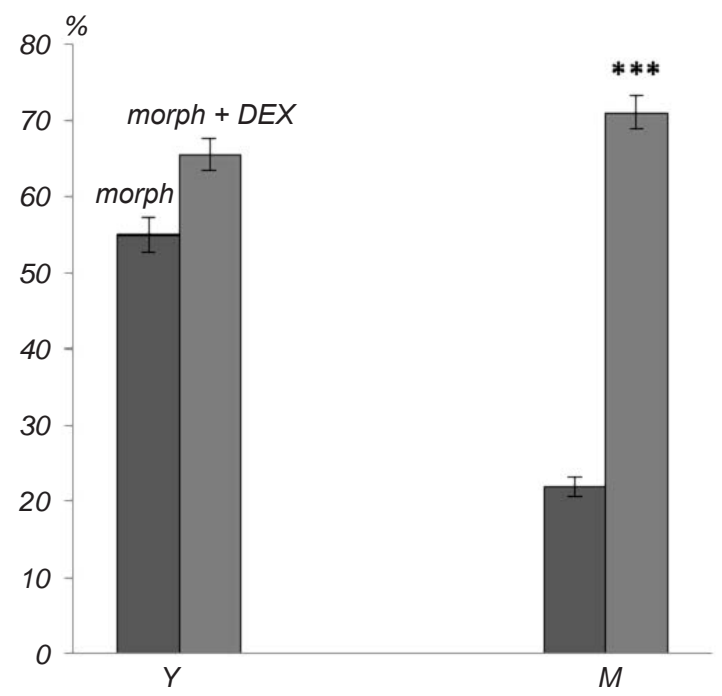

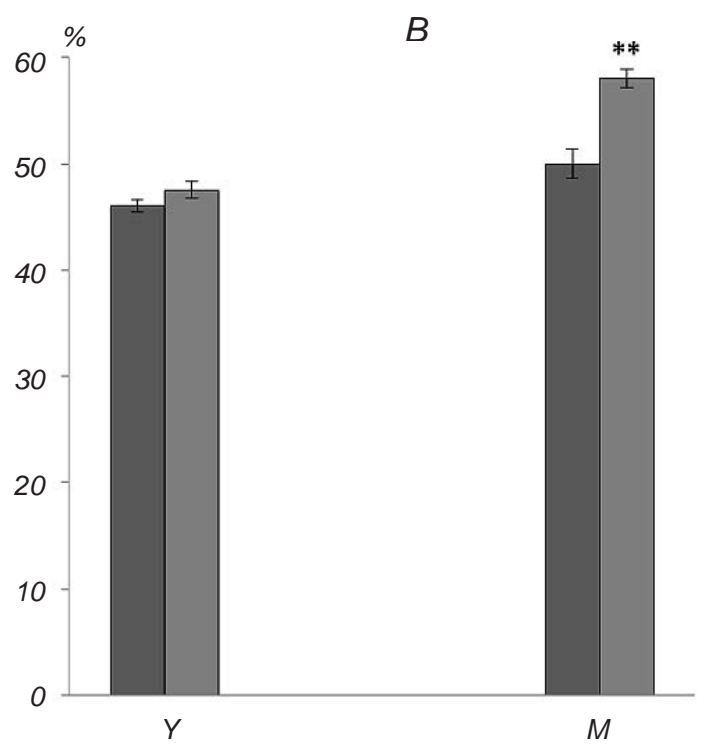

F i g. 2. Effects of co-injections of $5 \mathrm{mg} / \mathrm{kg}$ morphine and $1 \mathrm{mg} / \mathrm{kg}$ dexamethasone in young and mature rats. Designations are similar to those in Fig. $1 .{ }^{* * P} P 0.01$ in comparison with the morphine $(5 \mathrm{mg} / \mathrm{kg})$-injected group.

Р и с. 2. Впливи комбінованих ін'єкцій 5 мг/кг морфіну та 1 мг/кг дексаметазону на молодих та зрілих щурів. 

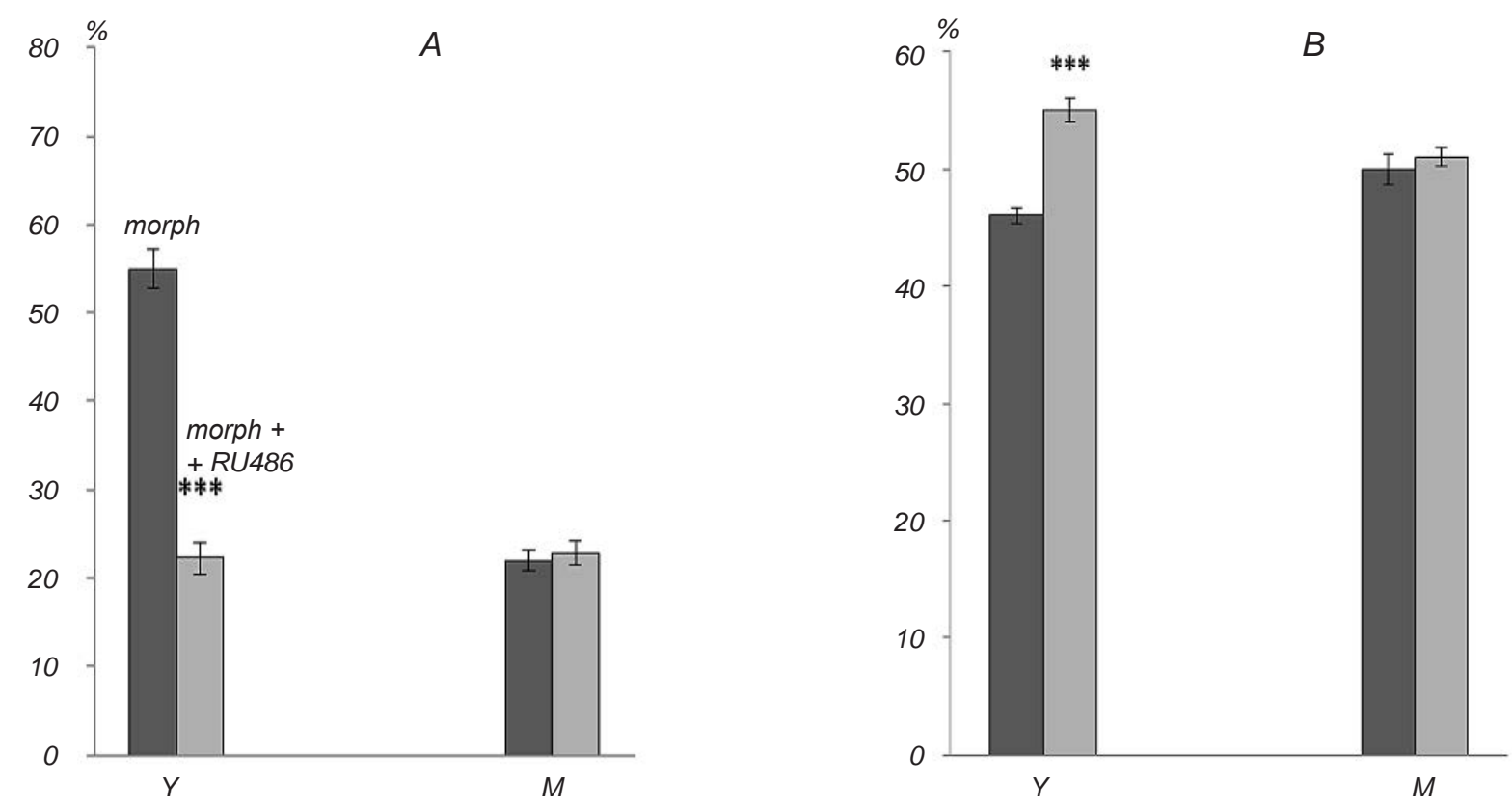

F i g. 3. Effects of $5 \mathrm{mg} / \mathrm{kg}$ morphine in the presence of RU486 $(20 \mathrm{mg} / \mathrm{kg})$ in young and mature rats. Designations are similar to those in Figs. 1 and $2 .{ }^{* * *} P<0.001$ in comparison with the morphine $(5 \mathrm{mg} / \mathrm{kg})$-injected group.

Р и с. 3. Впливи ін'єкцій 5 мг/кг морфіну в присутності RU486 (20 мг/кг) на молодих та зрілих щурів.
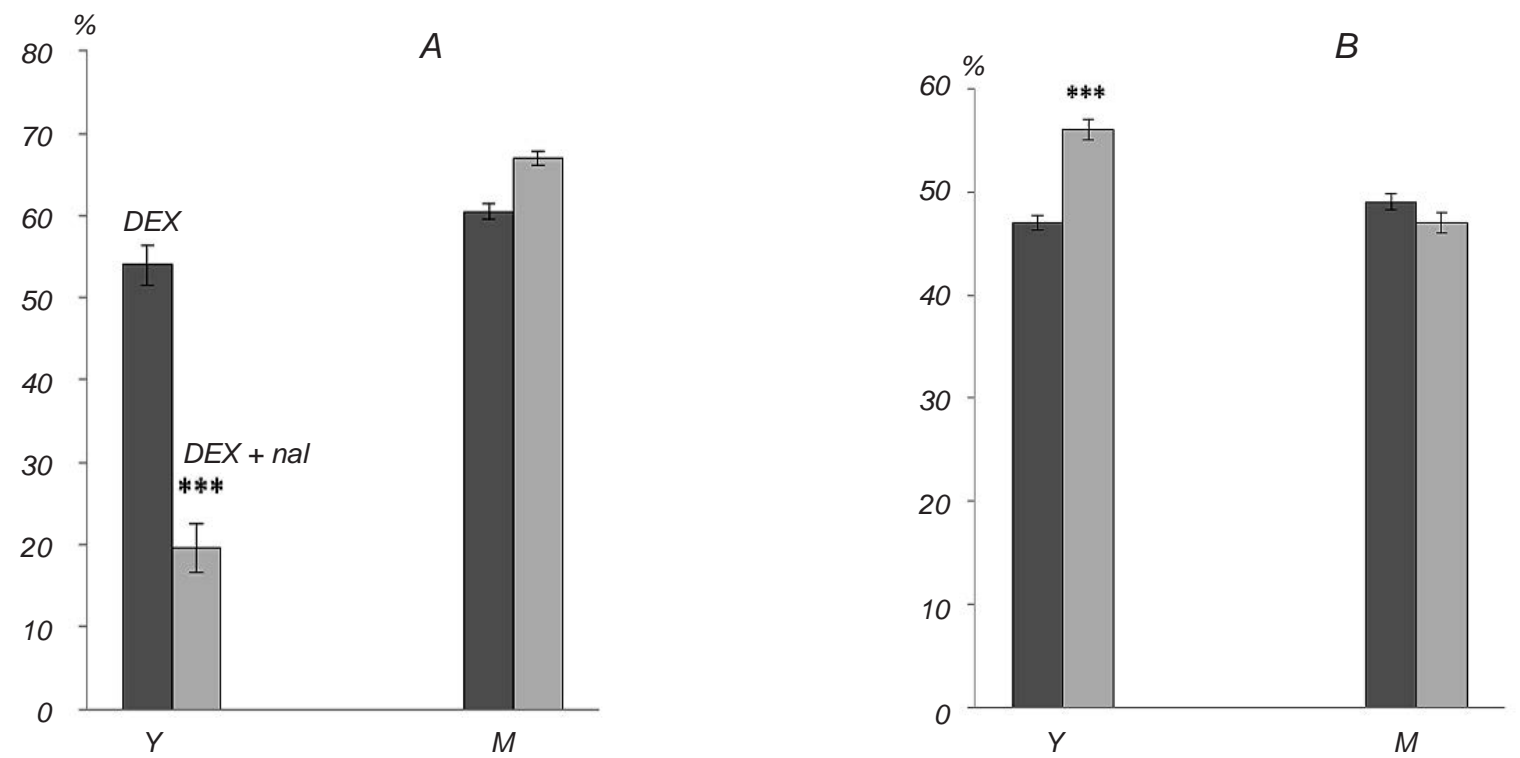

F i g.4. Effects of $1 \mathrm{mg} / \mathrm{kg}$ dexamethasone in the presence of naloxone (nal, $2 \mathrm{mg} / \mathrm{kg}$ ) in young and mature rats. Designations are similar to those in Figs. 1-3.***P $<0.001$ in comparison with the DEX $(1 \mathrm{mg} / \mathrm{kg})$-injected group.

Р и с. 4. Впливи 1 мг/кг дексаметазону в присутності налоксону (2 мг/кг) на молодих та зрілих щурів. 
young rats in the open arms under control conditions (saline injections) was significantly greater than the respective value in mature (3-month-old) individuals (Fig. 1A). This means that the anxiety level in mature rats is, in general, greater than in young ones, and morphine is more effective in decreasing this index in the latter age group. Injections of the abovementioned drugs induced mild (but significant) decreases in the index of locomotor activity in young rats but exerted nearly no effect on this index in elder (mature) animals (Fig. 1B). Combined injections of morphine and DEX $(1 \mathrm{mg} / \mathrm{kg})$ evoked anxiolytic effects in young rats nearly similar to those provided by isolated applications of morphine. In mature rats, such combined injections induced much more intense effects with this respect than introductions of morphine alone $(P<0.001)$ (Fig. 2A). Closed arm entries (characterizing the intensity of locomotor activity) did not change at such a combination (in comparison with "pure" morphine effects in young animals). In mature ones, the respective index moderately but significantly increased at the above combination $(P<0.001)$ (Fig. 2B).

There were significant differences in the percentage of time in the open arms and that of the closed arm entries (or locomotor activity) between the group that received RU486 $(20 \mathrm{mg} / \mathrm{kg})+$ morphine $(5 \mathrm{mg} / \mathrm{kg})$ in comparison with the only-morphine ( $5 \mathrm{mg} / \mathrm{kg}$ ) group, but this was observed exclusively in young rats $(P<$ $<0.001)$. At the same time there were no differences between these two groups of mature animals (Fig. 3). This means that the anxiolytic effect of morphine was prevented by RU486 only in immature rats. A mild (whereas significant) increase in the locomotor activity index was found in morphine + RU486-injected young rats, and such a difference was absent in mature animals (Fig. 3B). There were significant differences in the percentage of time in the open arms and in the index of locomotor activity in young rats that received $2 \mathrm{mg} / \mathrm{kg}$ naloxone $+1 \mathrm{mg} / \mathrm{kg}$ DEX in comparison with the DEX $(1 \mathrm{mg} / \mathrm{kg})$ group of such animals $(P<0.001)$. At the same time, there were no significant differences between these two groups in mature rats (Fig. 4A, B).

\section{DISCUSSION}

Our study showed that, in general, the level of anxiety is higher in older (mature) rats, which is in agreement with the data of previous studies of agerelated changes in the anxiety indexes in male rats in the elevated plus maze and light/dark tests [23-25].

Our results also showed that morphine $(5 \mathrm{mg} / \mathrm{kg})$ and also dexamethasone $(1 \mathrm{mg} / \mathrm{kg})$ induced significant increases in the percentage of time in the open arms, which clearly indicates an anxiolytic effect for both agents (Fig. 1). In young rats, morphine and dexamethasone noticeably reduced locomotor activity, and this was not observed in adult rats. Previous studies showed that the above doses of morphine and dexamethasone provide anxiolytic effects in adult (mature) animals, which is comparable with our results $[6,7,25]$. There were significant differences between the results of co-administration of morphine and DEX, in comparison with those of morphine alone, on anxiety behavior in adult rats, but this was not found in young rats. In mature rats, morphine co-injected with DEX increased the locomotor activity (Fig. 2B).

In previous studies, morphine was shown to induce clear corticosterone responses at doses of 20 or $30 \mathrm{mg} / \mathrm{kg}$, whereas no significant effect of morphine on the corticosterone levels was found at doses of 5 or $10 \mathrm{mg} / \mathrm{kg}$ [26]. These results are consistent with our results; it seems that a combination of two antianxiety drugs was partly related to the change in locomotor activities. Out results also showed that morphine in the presence of RU486 increased the anxiety level with a decrease in the percentage of time spent in the open arms in young rats. This fact was indicative of the increase in locomotor activity in these animals, but such an effect was absent in adult rats (Fig. 3). It seems that RU486 prevented noticeably the anxiolytic effect of morphine. It was shown that the inhibitory effect of RU486 is dose-dependent and linked to a decrease in the affinity of labeled dihydromorphine to $\mu$-opioid receptors [27]. Kinetic experiments demonstrated that RU486 induces a decrease in the association rate constant of dihydromorphine [27]. RU486 also was proved to be able to dissociate the dihydromorphine- $\mu$-opioid receptor complex [27]. RU486 inhibits binding of labeled dihydromorphine to $\mu$-opioid receptors present in membrane preparations derived from the rat and mouse brains, as well as in human neuroblastoma cells [27].

In addition, it was demonstrated that impairment of the receptor-dependent glucocorticoid action in the neonatal brain resulted in longer-lasting hormonal stress responses, reduction of locomotion phenomena, and an increase in the anxiety level in adulthood [28]. This discordance of the results with our data on adult rats can be related (at least partly) to differences in the protocols. As was shown in our study, naloxone 
inhibited the anxiolytic effect of dexamethasone and increased locomotor activity in young rats, but this was not observed in mature animals (Fig. 4). This result is in agreement with that of the study where no detectable increases in the plasma cortisol levels were found following both naloxone and saline administrations; this finding was indicative of effective opioid blockade at the level of hypothalamic-pituitary units $[6,29]$. This finding also indicates the involvement of a naloxone-sensitive pathway in mediation of the influences of glucocorticoids on anxiety.

There are two possible explanations for interaction between dexamethasone and naloxone in the anxiety state. First, it is likely that dexamethasone activates the endogenous opioid system, and the latter mediates the respective influences on anxiety. Although, there is some evidence indicating that the effects of DEX on such phenomena as analgesia and emotional memory are mediated (at least in part) by the endogenous opioid system [30]. However, there are, to our knowledge, no reports in the literature concerning such mediation of anxiety. Another explanation for these results might be that naloxone interacts with stress- and anxietyinduced glucocorticoids (or dexamethasone) in the plasma membranes of target neurons in the brain [31].

Therefore, our study showed that both opioid and glucocorticoid receptor agonists are effective to reduce the anxiety level in young and mature rats. Blocking of these receptors influences the above level in young rats noticeably stronger than that in adults this fact may be related to considerable dissimilarities of the neural and hormonal system activities in young and mature animals.

Acknowledgement. This study was supported by the Shahid Chamran University of Ahvaz, Iran, grant number $92 / 302 / 18672$. Hereby, the researchers of this study would like to express their sincere gratitude to the esteemed Vicepresidency of the Shahid Chamran University for their financial and moral supports.

All experimental procedures were carried out in accordance with international and institutional guidelines for animal care and use.

The authors, M. Kesmati, M. Rezai and M. Torabi, confirm that they have no conflicts of any kind related to the commercial or financial problems, relations with organizations or persons, which could in any way be associated with the investigation, and with the relationship of the co-authors of the article.
M. Кесматі ${ }^{l}$, М. Резаї ${ }^{1}$, М. Торабi ${ }^{1}$

\section{МОДУЛЯТОРНІ ВПЛИВИ ГЛЮКОКОРТИКОЇДНОЇ ТА \\ ОПІӦ̈ДНОЇ СИСТЕМ НА ПОВ' ЯЗАНУ $З$ ТРИВОЖНІСТЮ ПОВЕДІНКУ МОЛОДИХ ТА ЗРІЛИХ ЩУРІВ}

\author{
${ }^{1}$ Університет Шахід Чамран, Ахваз (Іран). \\ Р е $з$ ю м е
}

Враховуючи недостатню інформацію щодо взаємних впливів глюкокортикоїдів та опіоїдної системи на поведінку та залежність відповідних ефектів від віку, ми вивчали впливи введення 1 мг/кг дексаметазону та 20 мг/кг RU486 (агоніста та антагоніста глюкокортикоїдних рецепторів), а також 5 мг/кг морфіну та 20 мг/кг налоксону (агоніста та антагоніста опіоїдної системи) на рівень тривожності в тесті підвищеного лабіринту у молодих та зрілих щурів-самців. Нормовані значення часу, проведеного у відкритих рукавах лабіринту, та аналогічні значення кількості входів до закритих рукавів розглядались як індекси рівня тривожності та інтенсивності локомоторної активності відповідно. Уведення 5 мг/кг морфіну та 1 мг/кг дексаметазону зумовлювали значні анксіолітичні ефекти як у молодих, так i у зрілих щурів; дані агенти істотно знижували локомоторну активність тільки у молодих тварин. RU486 міг усувати анксіолітичні ефекти морфіну. Анксіолітичний вплив дексаметазону гальмувався налоксоном у молодих щурів, але цього не спостерігалось у зрілих тварин. Такі результати свідчать про існування істотної взаємодії глюкокортикоїдів та опіоїдної системи в їх функції опосередкування рівня тривожності та про значну залежність відповідних ефектів від віку.

\section{REFERENCES}

1. J. L. Barr and G. L. Forster, "Serotonergic neurotransmission in the ventral hippocampus is enhanced by corticosterone and altered by chronic amphetamine treatment," Neuroscience, 182, 105-114 (2011).

2. G. P. Chrousos, "Stressors, stress, and neuroendocrine integration of the adaptive response," Ann. New York Acad. Sci., 851, 311-335 (1998).

3. C. Tsigos and G. Chrousos, "Hypothalamic-pituitary-adrenal axis, neuroendocrine factors and stress," J. Psychosom. Res., 53, No. 4, 865-871 (2002).

4. M. P. Boyle, B. J. Kolber, S. Vogt, et al., "Forebrain glucocorticoid receptors modulate anxiety-associated locomotors activation and adrenal responsiveness," J. Neurosci., 26, No. 7, 1971-1978 (2006).

5. L. Velisek, "Prenatal exposure to beta-methasone decreases anxiety in developing rats: hippocampal neuropeptide $\mathrm{Y}$ as a target molecule," Neuropsychopharmacology, 31, No. 10, 2140-2149 (2006). 
6. A. A. Vafaei, A. Rashidi-Pour, and A. A. Taherianpak, "Peripheral injection of dexamethasone modulates anxiety related behaviors in mice: an interaction with opioidergic neurons," Pak. J. Pharm. Sci., 21 No. 3, 285-289 (2008).

7. R. Anand, K. Gulati, and A. Ray, "Pharmacological evidence for the role of nitric oxide in the modulation of stressinduced anxiety by morphine in rats," Eur. J. Pharmacol., 676, Nos. 1/3, 71-74 (2012).

8. A. Rezayof, S. Assadpour, and S. Alijanpour, "Morphineinduced anxiolytic-like effect in morphine-sensitized mice: involvement of ventral hippocampal nicotinic acetylcholine receptors," Pharmacol. Biochem. Behav., 103, No. 3,460-466 (2013).

9. M. Torabi, M. Kesmati, H. E. Harooni, and H. Najafzadeh varzi, "Effect of intra $C A 1$ and intraperitoneal administration of opioid receptor modulating agents on the anxiolytic properties of nano and conventional $\mathrm{ZnO}$ in male rats," Cell. J., 16, No. 2, 163-170 (2014).

10. R. N. Pechnich, "Effects of opioids on the hypothalamic pituitary adrenal axis," Ann. Rev. Pharmacol. Toxicol., 32, 353-382 (1993).

11. D. M. Ignar and C. M. Kuhn, "Effects of specific $\mathrm{Mu}$ and Kappa opiate tolerance and abstinence on hypothalamopituitary-adrenal axis secretion in the rat," J. Pharmacol. Exp. Ther, 255, No. 3, 1287-1295 (1990).

12. G. Lim, S. Wang, Q. Zeng, et al., "Spinal glucocorticoid receptors contribute to development of morphine tolerance in rats," Anesthesiology, 102, No. 4, 832-837 (2005).

13. M. V. Millanes, M. L. Laorden, M. Chapleur-Chateau, and A. Bulert, "Differential regulation of corticotrophinreleasing factor and vasopressin in discrete brain regions after morphine administration: correlation with hypothalamic noradrenergic activity and pituitary adrenal response," Naunyn. Schmiedebergs. Arch. Pharmacol., 356, No. 5, 603-610 (1997).

14. B. Nock, T. Cicero, and M. Wich, "Chronic morphine increases the pituitary-adrenocortical response of juvenile rats to mild stress," Pharmacol., Biochem., Behav., 80, No. 1, 7785 (2005).

15. K. Bennett, K. Manassis, S. D. Walter, et al., "Cognitive behavioral therapy age effects in child and adolescent anxiety: an individual patient data metaanalysis," Depress. Anxiety, 30, No. 9, 829-841 (2013).

16. P. Boguszewski and J. Zagrodzka, "Emotional changes related to age in rats-a behavioral analysis," Behav. Brain Res., 133, No. 2, 323-332 (2002).

17. S. Koukouli, V. Pattakou-Parasyri, and A. E. Kalaitzaki, "Self-reported aging anxiety in greek students, health care professionals, and community residents: A comparative study," Gerontologist, 54, No. 2, 201-210 (2013).

18. J. M. Bessa, M. Olivera, J. J. Cerqueira, et al., "Age-related qualitative shift in emotional behavior: Paradoxical findings after re-exposure of rats in the elevated-plus maze," J. Behav. Brain Res., 162, No. 1, 135-142 (2005).

19. P. J. Kamphuis, G. Croiset, J. M. Bakker, et al., "Neonatal dexamethasone treatment affects social behavior of rats in later life," Neuropharmacology, 47, No. 3, 461-474 (2004).

20. G. Lim, S. Wang, Q. Zeng, et al., "Expression of spinal NMDA receptor and PKCgamma after chronic morphine is regulated by spinal glucocorticoid receptor," J. Neurosci., 25, No. 48, 11145-11154 (2005).

21. L. Uriguen, B. Fernandez, E. Romerto, et al., "Effects of 14-methoxymetopon, apotent opioid agonist, on the responses to the tail electric stimulation test and plus-maze activity in male rats: Neuroendocrine correlates," Brain Res. Bull., 15; 57, No. 5, 661-666 (2002).

22. L. Laue, G. P. Chrousos, D. L. Loriaux, et al., "The antiglucocorticoid and antiprogestin steroid RU 486 suppresses the adrenocorticotropin response to ovine corticotropin releasing hormone in man," J. Clin. Endocrinol. Metab., 66, No. 2, 290-293 (1988).

23. S. Ferguson and E. Gray, "Aging effects on elevated plus maze behavior in spontaneously hypertensive, Wistar-Kyoto and Sprague-Dawley male and female rats," Physiol. Behav., 85, No. 5, 621-628 (2005).

24. A. E. Arrant, N. L. Schramm-Sapyta, and C. M. Kuhn, "Use of the light/dark test for anxiety in adult and adolescent male rats," Behav. Brain Res., 256, 119-127 (2013).

25. E. Mikics, B. Barsy, B. Barsvari, and J. Haller, "Behavioral specificity of non-genomic glucocorticoid effects in rats: Effects on risk assessment in the elevated plus-maze and openfield," Hormon Behav., 48, No. 2, 152-162 (2005).

26. G. Fuertes, M. Milanes, M. Rodriguez-Gago, et al., "Changes in hypothalamic paravenricular nucleus catecholaminergic activity after acute and chronic morphine administration," Eur. J. Pharmacol., 388, No. 1, 49-56 (2000).

27. R. Maggi, F. Pimpinelli, L. Casulari, and F. Martini, "Antiprogestins inhibit the binding of opioids to $\mu$-opioid receptors in nervous membrain preparations," Eur. J. Pharmacol., 301, Nos. 1/3, 169-177 (1996).

28. S. G. Pivina, V. K. Akulova, and N. E. Ordian, "The impact of early developmental impairment of the receptor-dependent glucocorticoid action on the pituitary adrenal axis activity and behavior of male rats," Ross. Fiziol. Zh. im. I. M. Sechenova., 96, No. 1, 69-76 (2010).

29. M. Campo, J. Sotres, K. Ferra, and A. Aguirre, "High dose naloxone $(1 \mathrm{mg} / \mathrm{kg})$ : Psychological and endocrine effects in normal male subjects pretreated with one milligram of dexamethasone," Psychoneuroendocrinology, 23, No. 4, 413424 (1998).

30. A. Rashidy-Pour, H. Sadeghi, A. A. Taherian, et al., "The effects of acute restraint stress and dexamethasone on retrieval of long-term memory in rats: an interaction with opiate system," Behav. Brain Res., 23; 154, No. 1, 193-198 (2004).

31. S. J. Evans, T. F. Murray, and F. J. Moore, "Partial purification and biochemical characterization of a membrane glucocorticoid receptor from an amphibian brain," J. Steroid. Biochem. Mol. Biol., 72, No. 5, 209-221 (2000). 